\title{
THE PRESENT AND FUTURE OF SZIGETVÁR SPA - AN ECONOMIC ANALYSIS OF GEOTHERMAL ENERGY INVESTMENT
}

Judit PÁLNÉ SCHREINER, engineering instructor

University of Pécs Pollack Mihaly, Faculty of Engineering and Information Technology, Faculty of Business and Economics

Address: $\quad$ H7625 Pécs, Böck János u.33.

Phone: $\quad+36303134820$

E-mail: judit.schreiner@gmail.com 


\title{
THE PRESENT AND FUTURE OF SZIGETVÁR SPA - AN ECONOMIC ANALYSIS OF GEOTHERMAL ENERGY INVESTMENT
}

Keywords: Economic analysis, Geothermal energy, Investment, Renewable energy, Szigetvár, Thermal water

\begin{abstract}
In Hungary, geothermal energy has proved to be an economical source of energy for direct use. It highlights the pros and cons of including renewable energy in the power generation mix of Hungary, and the pros and cons of local application. This paper looks at the operation of Szigetvár Spa from both economic and social aspects. In this study, qualitative analysis is used for the basic economic and social introduction of the Spa, and then real options, based on quantitative methods, are described to identify the long-term financial consequences of the project.

In 1966, thermal water was found in Szigetvár. In 1997, this thermal water was certified as medicinal water. The wellhead temperature of Szigetvár thermal water is $62^{\circ} \mathrm{C}$ in the 790 metres deep thermal well. It is used as so-called domestic hot water in the Szent István housing estate and in Szigetvár Spa. One of the problems with the project is that it is based on single stage thermal water utilization, another problem is that the waste water is too hot. This can be solved by exploiting the heat energy of thermal water more intensively. This way, maximum benefits can be gained from geothermal energy with minimum use of energy. Static and dynamic investment analyses were carried out to examine the spa from a financial aspect. The methods used include static payback period, average rate of return, levelized cost of electricity, net present value, profitability index, dynamic payback period, internal rate of return and real options.

By pricing geothermal technology, it is possible to identify the strategic value of flexibility, to quantify what was previously left unquantified, and thus to show that geothermal investments are profitable not only from a social but also from a financial aspect as well.
\end{abstract}

\section{INTRODUCTION}

The economy of the South Transdanubian region has been unable to create a new development track since the change of regime. The result is general impoverishment, the increasing shortage of jobs and the mass emigration of young qualified professionals from the Region. The bad experiences of past decades underscore that external development resources can be expected only to a limited extent so it is vitally important how the region's internal, mainly naturally available, resources can be put to use.

The Region has natural resources which can be utilized to establish an internationally competitive economic condition (European Commission, 2009; Mádlné Szőnyi, 2009).In recent years, several facilities using geothermal energy started their operations in South Transdanubia which can be evaluated in terms of operating experiences ( Bobok -Tóth, 2010; Magyarország Megújuló Energia Hasznosítási Cselekvési Terve, 2011). In my research I chose to study Szigetvár's thermal network (heating of housing estate and spa) as a model unit. 
The study aimed at identifying the key investment and operational data of this marketbased facility, the profitability of the business, evaluating the experiences, assessing the difficulties and defining the most promising lines of development for the Region.

\section{INTRODUCTION OF SZIGETVÁR AND SZIGETVÁR'S THERMAL NETWORK ${ }^{42}$}

The past of Szigetvár is closely connected with the history of the castle. The settlement is located in the flood area of Almás Creek. An ever-important traffic and commercial route has lead across this soggy area inhabited for millennia. At the time of Hungarian conquest, Botond's tribe settled around here, and the creation of an urban settlement was due to the work of monastic orders.

By the $15^{\text {th }}$ century a medieval town was formed surrounded by a castle to provide safety. After the battle of Mohács (1526), both the castle and the town were fortified, and the islands were flooded around by Almás Creek dammed to form a lake. Following the siege of Buda in 1541, Szigetvár became royal property. The king recognized the significance of the castle and established a permanent garrison there. However, the castle was taken by the Turks in 1566 , who rebuilt it into what can be seen today. In the area of present-day Baranya county, the Turkish occupation lasted here the longest until February 1689.

By the mid- $18^{\text {th }}$ century Szigetvár lost its military importance, and the castle went into the hands of a landlord. At the end of $19^{\text {th }}$ century, following the construction of PécsBarcs railway line, the town was able to connect to the country's economy and big factories were established, such as the steam mill in 1881, the shoe factory in 1884 , and the cannery in 1937. Owing to centuries of development, Szigetvár was ranked to be a town in 1966 on the $400^{\text {th }}$ anniversary of a heroic fight (www.szigetvar.hu).

In 1966, 400 years after fighting with the Turks, thermal water was found while drilling for oil near Szigetvár castle. The so-called thermal well No. 1 is 790 meter deep and yields $62^{\circ} \mathrm{C}$ water (Szederkényi, 2003). As it is a positive well (water comes with a pressure of about 1 bar), water is brought to the surface in a natural way, a pump is only required for transport. The well is operated by Sziget-Víz Kft. Two additional wells can be found in the same water reserve. Well No. 3 is operated by Szeszico Kft. situated in the area of Szigetvár. The company grows tomato in its greenhouses by using a

\footnotetext{
${ }^{42}$ Technical data are taken from Sziget-Víz Kft.
} 
remarkable technology. Water is used to heat the greenhouses then it is reinjected into the ground through well No. 2.

Water from thermal well No. 1 operated by Sziget-Víz Kft. is used in two ways. On the one hand, this water is used as domestic hot water in Szigetvár's Szent István housing estate. This water was previously used for heating the housing estate too but the aggressive water corroded the pipelines. Currently on annual level, about 35-40 thousand $\mathbf{m}^{\mathbf{3}}$ of rated mineral water is used for bathing, washing and cooking by Szigetvár residents living in the nearly 800 flats of the housing estate. The other function is water use by the (supply for) Szigetvár Spa where 300-320 thousand $\mathrm{m}^{3}$ of water is used a year. Apart from these areas of use, we also have to calculate with interim water leakage. As water output is steady but water use is not, loss is inevitable, although a buffer tank is in place to reduce it. It would be possible to directly control water output but meddling with stable pressure conditions in the well is a hydrological risk which could cause a drop in the yield of thermal well (Pálné Schreiner, 2013).

The ideal temperature for spa operations is $40-41^{\circ} \mathrm{C}$ (Mádlné Szőnyi, 2006). As the entering water temperature is $59{ }^{\circ} \mathrm{C}$, water cooling is a permanent task. Heat absorption in winter can be realized by heating several institutions. Used water goes to heat an apprentice shop, a sports changing room, the Kumilla hotel, the spa building, the training pool, and the outdoor circulated pool of the spa. These can be safely heated this way until minus $10-15^{\circ} \mathrm{C}$. In extreme cold $\left(-25^{\circ} \mathrm{C}\right)$, the apprentice shop, the sports changing-room and the outdoor pool would be disconnected from the linked-up facilities. So far no large-scale intervention has been needed in the operations of the spa. In summer the above opportunities for heat absorption are applicable only to a limited extend, therefore cooling water is used to reduce water temperature entering the spa. The cooling water well is also located in the area of thermal well. Cooling water is let out into the boating lake of the castle park.

The temperature of hot water used and wasted in the spa is $32-35^{\circ} \mathrm{C}$. This so-called waste water is let partly into the sewer and partly into the Almás Creek. Unfortunately, its reuse remains unsolved.

During the analysis of thermal water in 1997, it was discovered that the thermal water of Szigetvár is one of the best quality and most effective medicinal water with highly therapeutic potential (www.szigetvarigyogyfurdo.hu). By analysis, the thermal water contains sodium chloride and alkaline hydrogen carbonates, being highly effective in the therapy of joints, rheumatism and locomotive organs. Regularly using the water, its high 
fluoride content slows down old-age osteoporosis, and it has proved excellent in postoperational and post-fracture rehabilitation, as well as treating gynecological problems and curing prostate complaints. The spa is also recommended to people suffering from hypertension, vascular and heart diseases (www.szigetvarigyogyfurdo.hu).

After three years of construction (2004-2007), Szigetvár Spa opened its gates in the place of the old thermal bath in September 2007. The spa is operated by Sziget-Víz Kft. The company, along with the local government, also acted as co-investor in the investment. The spa has two medicinal pools, a thermal water splash pool, a guitar-shaped beach pool, a sports pool, a children's pool and a Jacuzzi. The spa also offers wellness services, Finnish and infra sauna, as well as a steam cabin for its guests. Relying on the outstanding quality of its medicinal water, the spa operates a medical department offering complex curative care. Contracted by the National Health Insurance Fund, patients can use a number of medical services on a social security basis (www.szigetvarigyogyfurdo.hu).

\section{ECONOMIC DATA ${ }^{43}$}

\section{INVESTMENT COSTS}

The Szigetvár Spa development was realized by Szigetvár Local Government in the years 2004 to 2007. The project received HUF 400,000,000 support from the current Széchenyi tender allocation. Other external, non-refundable resources were not involved in the project. The construction costs of spa buildings were HUF $1,129,627,821$. The purchase cost of equipment was HUF 64,977,421. The broad list of equipment ranges from office desks to computers, to deck chairs, and medical mattresses. Spa construction also included a sports pool, a children's pool, outdoor flooring, fences and a drilled well. The investment cost of these facilities was HUF 99,456,109.

The investment cost at Szigetvár Spa was HUF 1,294,061,351; the breakdown is shown in Table 1.

\footnotetext{
${ }^{43}$ Financial data are taken from Sziget-Víz Kft.
} 
Table 1 Breakdown of total investment costs of Szigetvár Spa

\begin{tabular}{|l|r|}
\hline Description & HUF \\
\hline Building & $1,129,627,821$ \\
\hline Facility & $99,456,109$ \\
\hline Equipment & $64,977,421$ \\
\hline Total & $\mathbf{1 , 2 9 4 , 0 6 1 , 3 5 1}$ \\
\hline
\end{tabular}

Source: Sziget-Víz Kft., edited by Judit Pálné Schreiner

\section{OPERATING COSTS}

\section{Direct trading cost}

Direct trading cost consists of three items, namely, material-type expenses, personnel expenditures and combined direct expenses. In material-type expenses, the basic fee for water reserve tax (mining royalties) is HUF $4.5 / \mathrm{m}^{3}$ in case of medical use, and a five-fold factor applies in case of public use. This cost amounted to HUF 9,915,381 at Szigetvár Spa in 2011. Depreciation is calculated at $2 \%$ for buildings and $14 \%$ for machinery. IT equipment is depreciated in 2 years, while equipment valued under HUF 100,000 is depreciated on a case- by-case basis, typically in a lump sum. So depending on the amount of assets valued under HUF 100,000 (deck chairs, small machinery etc.) and the IT equipment (monitors, printers), the annual depreciation cost varies; in 2011 depreciation was calculated at HUF 10,728,057. In 2011 material-type expenses amounted to HUF $58,839,189$ at Szigetvár Spa. In 2011, personnel expenditures such as salaries expense, payments to personnel and salaries tax totaled HUF 52,139,564; combined direct expenses such as transportation, machinery cost, maintenance cost and laboratory cost were HUF $5,831,635$. Based on the above, direct trading cost in 2011 was HUF 116,810,388.

\section{Indirect sales cost}

I used operation-based accounting during the research. The item indirect sales cost is a collective term at Szigetvár Spa. It includes items which are difficult to break down under given headings, such as the salaries and other expenses of company management, maintenance cost of the central building, expenses of administrative personnel (bookkeeping, wages accounting). In 2011 these costs totaled HUF 56,528,683 at Szigetvár Spa. In 2011 the operating cost was HUF 173,339,071 at Szigetvár Spa. 


\section{OPERATIONAL COST}

The operational cost is given by subtracting depreciation from operating cost, i.e., Operational cost $=$ Operating cost - Depreciation $=$ HUF 173,339,071 - HUF 10,728,057 $=$ HUF 162,611,014. In 2011 the operational cost was HUF 162,611,014 at Szigetvár Spa.

\section{OPERATING SALES INCOME}

In 2011 the operating sales income was HUF 154,524,137 at Szigetvár Spa. The points and amount of sales income are shown in Table 2.

Table 2 Operating sales income at Szigetvár Spa in 2011

\begin{tabular}{|l|r|}
\hline Points of sales income at Szigetvár Spa & HUF \\
\hline Support from National Health Insurance Fund & $23,024,493$ \\
\hline Payments from voluntary or private health insurers & 0 \\
\hline Value of redeemed holiday vouchers & $13,006,950$ \\
\hline Entry fees & $100,645,696$ \\
\hline Season ticket sales & 675,000 \\
\hline District heat sales (DHW) & $11,525,000$ \\
\hline Other income & $6,046,998$ \\
\hline Total sales income & $\mathbf{1 5 4 , 5 2 4 , 1 3 7}$ \\
\hline
\end{tabular}

Source: Sziget-Víz Kft., edited by Judit Pálné Schreiner

\section{FINANCIAL ANALYSIS}

To achieve the highest return on the investment, various analytical tools help identify the best alternative or the best combination of alternatives. The most commonly used methods are: determining the discounted value of the total life cycle unit cost of energy generated by the realized investment; calculating the modified internal rate of return; and determining the saving/invested capital ratio, when there are no actual revenues, only cost savings (RenEnergy, 2004). The calculations which form the basis of investment decisions can be divided into two large groups, the static and dynamic analyses of investment profitability. 


\section{STATIC INVESTMENT ANALYSIS}

A common feature of static analyses is that they ignore the time value of money, i.e., they do not account for the time dimension of cash flows. These calculations are less complicated and cost-effective methods. The most widely used static calculations of investment profitability are as follows:

Cost comparison: Static cost-based methods calculate the project cost and the project unit cost by ignoring the time value of money. In this research, these are calculated per $\mathrm{kWh}$ and GJ, respectively.

Profit comparison: the difference of operating revenues and operating expenses in a given year, i.e., the operating cash flow of the investment.

Profit and loss calculation: profit projected on time. Two versions of cost/profit ratio have been calculated in the research: the ratio of investment cost over return and the return on owner's equity.

Payback period: payback time or period of the project. Shorter payback time is better than a longer one, but there is no clear rule as to how much shorter is considered better. The payback time method does not define the payback time needed for profit maximization, so it is not recommended to use as a selection tool in the assessment of durable assets (Hanyecz - Pálné Schreiner, 2013).

\section{STATIC ANALYSIS OF INVESTMENT PROFITABILITY OF THE SZIGETVÁR SPA}

\section{Net Income}

The operating revenue of the Szigetvár Spa in 2011 was HUF 154,524,137, the operating cost was HUF 173,339,071, and thus the loss at the spa was HUF - 18,814,934.

\section{Return}

The basis of return is the sum of Net Income and Depreciation, HUF -18,814,934+ HUF $10,728,057,=$ HUF $-8,086,877$.

Return on investment $=$ Total cost of investment $/$ Basis of return $=$ HUF 1,294,061,351 / HUF -8,086,877 -> return is not possible.

Return on owners' equity $=($ Total cost of investment - Tender allocation $) /$ Basis of return $=$ HUF 894,061,351/ HUF -8,086,877 -> return is not possible Since no profit was generated, it was impossible to calculate return. 


\section{Unit cost of fuel}

Annually, the spa uses $386,900 \mathrm{~m}^{3}$ of thermal water, $80 \%$ of which is $59^{\circ} \mathrm{C}$. The amount of energy in this water is $31,864 \mathrm{GJ}(8,851,182 \mathrm{kWh})$. This value has been calculated based on the quantity of medicinal water used in the spa, whereas it doesn't include the amount of energy contained in water leakage.

Unit cost of $1 \mathbf{k W h}$ of energy = Operating expenses / Amount of replaced energy = HUF 173,339,071 / 8,851,182 kWh $=\mathbf{1 9 . 6 0 ~ H U F / k W h ~}$

Unit cost of 1 GJ of energy = Operating expenses / Amount of replaced energy = HUF 173,339,071 / 31,864 GJ = 5,440 HUF/GJ

$1 \mathrm{~m}^{3}$ of natural gas means $10 \mathrm{kWh}$ of energy at a caloric value of $36 \mathrm{MJ} / \mathrm{m}^{3}$. Thus the above amount of energy could be produced by using $885,118 \mathrm{~m}^{3}$ of gas.

Unit cost of $1 \mathbf{m}^{3}$ of replaced gas = Operating expenses $/$ Volume of replaced gas = HUF $173,339,071 / 885,118 \mathrm{~m}^{3}=\mathbf{1 9 5 . 8} \mathbf{H U F} / \mathbf{~ m}^{\mathbf{3}}$

Unit production cost of $1 \mathbf{m}^{3}$ of thermal water = Operating expenses / Volume of thermal water extracted $=$ HUF 173,339,071 / 386,900 $\mathrm{m}^{3}=\mathbf{4 4 8} \mathbf{H U F} / \mathbf{m}^{\mathbf{3}}$

The investor in Szigetvár doesn't take into account the savings on gas fee as a source of 'revenue' in the calculation of operating revenues. If we consider that in order to reach the ideal water temperature of the Szigetvár Spa $\left(40-41^{\circ} \mathrm{C}\right)$, the incoming 59 degree water is used to heat the school's apprentice shop, a sports changing room, the Kumilla hotel, the building of the training pool, the town's sports hall and the spa building - nearly $36,772 \mathrm{~m}^{3}$ of space volume - then the net income of the investment looks as follows.

\section{Savings on gas fee}

As the result of development, the geothermal energy provides the heating of $36,772 \mathrm{~m}^{3}$ of space volume. In 2011, this allowed saving 6,251 GJ (1,736 mWh) of energy, which corresponds to $233,906 \mathbf{~ m}^{3}$ of gas (back calculated from the amount of heat). It resulted in $6,251,000 \mathrm{MJ} * 3.741 \mathrm{HUF} / \mathrm{MJ}=\mathrm{HUF} 23,384,991$ of savings on gas fee in 2011. The operating 'revenue' increased by gas fee is HUF 154,524,137 + HUF 23,384,991 = HUF 177,909,128. Thus the net income of the spa in 2011 is HUF 177, 909,128 - HUF 173,339,071 = HUF 4,570,057 profit. 


\section{Payback period of the operating revenue adjusted by gas fee}

The basis of return (its source) is the sum of Net Income and Depreciation, HUF 4,570,057 + HUF 10,728,057 = HUF 15, 298,114.

Payback period of investment $=$ Total cost of investment $/$ Basis of return $=$ HUF $1,294,061,351 /$ HUF $15,298,114=\mathbf{8 4 . 6}$ years

Payback period of owners' equity $=($ Total cost of investment - Tender funds $) /$ Basis of return $=$ HUF 894,061,351/HUF 15,298,114 = 58.4 years

\section{DYNAMIC INVESTMENT ANALYSIS}

Practice usually supports decision-making which is based on dynamic investment calculations. The most commonly used framework for investment assessment is discounted cash flow (DCF). In the research, the following DCF methods have been used for the calculation: net present value, total life cycle cost, total life cycle unit cost, internal rate of return, modified internal rate of return, and dynamic payback period (Bélyácz I., 2009).

An investment project with steady cash flows can be best assessed by the net present value (NPV) method in a deterministic environment. Based on the cash flows, the framework identifies the future net cash flows (usually on annual level), and then it discounts them at a risk-adjusted rate so that they are expressed as the present value of cash amounts (Csapi V., 2013). If the net present value is greater than zero, the investment is profitable, and the metric suggests the decision maker that the investment should be realized; if the net present value is less than zero, the investment is uneconomical and should be rejected.

The method of total life cycle cost (TLCC) accounts for the cost factors from the point of view of a single player, the electricity generating company, i.e., the power plant owner. The method ignores both the impacts on the broader electricity grid and the externalities important to the environment and society; it only observes $\mathrm{CO}_{2}$ emission. The method calculates the cost during the total life cycle of the power generation facility.

The metric of levelised cost of energy (LCOE) distributes the expenses over the present value of the amount of power output. There are two methods in use. The one used by the International Energy Agency (IEA) discounts future costs then divides the result by the present value of future output. The other, so-called annuity method is based on the present value of the sum of future cost flows, and then it derives a cost equivalent which is divided by the average annual electric energy output. If, during discounting, the same cost of 
capital is used in both methods, and the same levelising rate in the annuity formula, the results will be equal.

The internal rate of return of an investment (IRR) is the average return realized annually. The investment is acceptable if the returns are greater than the cost of capital, i.e., the cost of funds used to realize the investment. Regarding IRR value, the cost of capital is the minimum rate of return that is acceptable.

The modified internal rate of return (MIRR) resolves the ranking conflict resulting from the different assumptions of reinvestment rate for the two most commonly used investment calculations, net present value and internal rate of return, in that it calculates the future value by assuming the reinvestment of project cash flows at the cost of capital. Then it looks at the discount rate at which the sum of future values will produce the present value of the sum of investment costs. The decision rule is the same as in the case of internal rate of return.

The discounted payback period (DPP) is the time period needed for the payback of the upfront investment cost, expressed in the future discounted cash flow (converted to present value). Cash flow items are discounted to the start of investment at a rate to express the uncertainty of future cash flow items in addition to the time value of money. The greater the uncertainty of future cash flow items, the bigger the cost of capital. The shorter the payback period, the better, regardless if the cash flow is discounted or not. It is still unclear how much shorter time is good. All we can know is that the investment, based on the discounted cash flow, can be precisely covered during the discounted payback period, at a time when the cumulated discounted cash flow breaks even with the initial amount of investment. This method, too, ignores a significant part of cash flows of the observed investments.

\section{DYNAMIC ANALYSIS OF INVESTMENT PROFITABILITY OF THE SZIGETVÁR} SPA

In the case of the Szigetvár Spa, the basis of calculation was $10 \%$ rate of cost of capital and 50 years of useful lifetime. The results are shown in Table 3. 
Table 3 Dynamic investment ratios of the Szigetvár Spa

Source: Sziget-Viz Kft. edited by Vivien Csapi

\begin{tabular}{|l|r|r|}
\hline & $\begin{array}{r}\text { Unit of } \\
\text { measurement }\end{array}$ & \multicolumn{2}{|c|}{ Szigetvár } \\
\hline Useful lifetime & year & 50 \\
\hline Cost of capital & $\%$ & 10 \\
\hline NPV & HUF & $1,249,370,532$ \\
\hline TLCC & HUF & $3,012,686,083$ \\
\hline LCOE & HUF/mWh & 39,980 \\
\hline IRR & $\%$ & NA \\
\hline MIRR & year & $3.60 \%$ \\
\hline DPP & & 1448 \\
\hline
\end{tabular}

The research results indicate that the Szigetvár thermal project is characterized by a high present value of total cost and unit cost. It does not create value on annual level, and after spreading out the modified internal rate of return, the investment has an annual rate of return of $3.6 \%$.

\section{DISCUSSION}

The operation of the Szigetvár Spa is sustainable in the long run since the geological studies suggest the availability of geothermal heat is unlimited (Liebe et al., 2001). Additional projects such as the development of cascade (multigrade) use of thermal water could further increase the profitability of the spa (Mádlné Szőnyi, 2006).

A possible location for the cascade use of water could be the Szent István housing estate. As the hot water pipeline network is outdated, consumers often complain about the quality of service. This problem could be solved by installing a thermostatic valve. This kind of technical solution would result in several hundreds of thousands $\mathrm{m}^{3}$ of water let out at the terminal points. The cooled down water could be transferred to Szeszico Kft. and used to heat greenhouses, then with the rest of used thermal water it could be pumped back into the water-yielding layer. As it can be done by installing a nearly 300-meter long pipeline, this could be an investment with fast return, improving the quality of service. Additionally, pumping back the water could ensure long-term sustainability. 
Another way to improve the quality of hot water could be the installation of circular pipeline network in the housing estate. Here the returning (cooled down) water could be pumped to the pools for use in the spa, with no extra cooling.

The cascade use of thermal water could also be realised with the 32-35 degree warm water let out from the spa. The cooled down water could be recycled to use for the heating of municipal buildings lying 300 to 400 meters away. A study on energy use states this heat loss would supply enough energy to heat Vígadó. Although these projects would involve extra costs, they could also increase the efficiency of the system.

\section{CONCLUSION}

Because of high investment costs, the utilization of alternative energy sources carries a substantial risk for the investors. Creation of efficient circular flows in the spa and thereby the profitability of the project can only be achieved by additional investments, which involve significant extra investment and expenses. At the same time, by using geothermal energy in Szigetvár, fossil fuel equivalent to 6,251 GJ of energy remains unburnt annually by replacing nearly $233,906 \mathrm{~m}^{3}$ of natural gas. Therefore the basic environmental benefit of the investment is reduction of $\mathrm{CO}_{2}$ emissions contributing to greenhouse effect. No other environmental effects (either negative or positive) are induced during the operation of the spa, so they cannot be quantified, and the built-in materials will not directly impact the environment, should the investment come to an end.

\section{REFERENCES}

Bélyácz, I. (2009). A befektetési döntések megalapozása, Budapest: Aula Kiadó Bobok, E., Tóth, A. (2010). A geotermikus energia helyzete, perspektívái. = Magyar Tudomány, Budapest, 2010/8. p. 926-936.

Csapi, V. (2013). Stratégiai beruházások a villamosenergia-szektorban A reálopcióelmélet alkalmazásának lehetöségei és korlátai a liberalizált villamosenergia-szektor egyedi és összetétel-szintü optimalizálási döntéshozatala során. Doktori értékezés, PTE-KTK Gazdálkodástani Doktori Iskola, Pécs, 2013

Data of medical water in Szigetvár, http://szigetvarigyogyfurdo.hu/\#kezdolap (last visited 28 February 2013)

Data of Szigetvar Spa, http://szigetvarigyogyfurdo.hu/\#medencek (last visited 28 February 2013)

European Commission (2009). Panorama of Energy. Energy statistics to support EU policies and solutions. Europen Commission, Luxembourg

Hanyecz, L., Pálné Schreiner, J. (2013). A szigetvári termálvíz felhasználásának gazdasági elemzése. in: Régiók fejlesztése - TÁMOP-4.2.1.B-10/2/KONV-2010-0002 projekt 
kutatászáró konferencia tanulmánykötete. Pécsi Tudományegyetem

Közgazdaságtudományi Kar, Pécs 2013. pp. 99-110. ISBN: 978-963-642-531-9

History of Szigetvár, http://szigetvar.hu/\#szigetvar_tortenete (last visited 28 February 2013)

History of Szigetvár, http://szigetvar.hu/\#szigetvar_tortenete (last visited 28 February 2013)

Liebe, P. et al. (2001). Tájékoztató. Termálvizkészleteink, hasznositásuk és védelmük. Környezetvédelmi Minisztérium megbízásából készítette a VITUKI Rt. Hidrológiai Intézete, Budapest. 2001. 29.p.

Mádlné Szőnyi, J. (2006). A geotermikus energia. Grafon Kiadó, Nagykovácsi, 2006. 144.p.

Mádlné Szőnyi, J. (2009). Fejlődési lehetőségek a geotermikus energia hasznosításában, különös tekintettel a hazai adottságokra In: Magyar Tudomány, Budapest, 2009/8. 989-1003.p.

Magyarország Megújuló Energia Hasznositási Cselekvési Terve 2010-2020. A 2020-ig terjedő megújuló energiahordozó felhasználás alakulásáról. Nemzeti Fejlesztési Minisztérium, $\quad$ 2011. április 19. 222.p. http://geotermia.lapunk.hu/tarhely/geotermia/dokumentumok/national_renewable_en ergy_action_plan_hungary_hu.pdf Download:2011.03.02.)

Pálné Schreiner J. (2013). Alternatív energiák hasznosítási megoldásainak vizsgálata. In: Buday-Sántha Attila (szerk.) Dél-Dunántúli régió fejlesztése II. kötet: TÁMOP4.2.1.B-10/2/KONV-2010-0002 „A Dél-Dunántúli régió egyetemi versenyképességének fejlesztése” című projekt „Dél-Dunántúl gazdasági erőforrásainak feltárása és fejlesztési lehetőségek meghatározása" című alprojekt kutatást záró monográfia. Pécsi Tudományegyetem, Pécs 2013. pp. 466-505. ISBN: 978-963-642-537-1

RenEnergy (2004). Economic Planning for Commercial Renewable Energy Projects Download: www.focusonenergy.com, 2009.04.10.

Szederkényi, T. (2003). Délkelet-Dunántúl ismert és reménybeli termálvíz készletei. In: Megújuló energiaforrások és a termálvíz többcélú hasznosítása, Mandulavirágzási Tudományos Napok, Konferenciakötet, Pécs, 2003. 29-32.p. 